\title{
Continuous-Flow Removal of Arsenic in Drinking Water by Filtering down through $\mathrm{Fe}_{3} \mathrm{O}_{4} @ \mathrm{SiO}_{2}$ Magnetic Composite
}

\author{
Virginia Montero-Campos, Allen Puente-Urbina \\ Centro de Investigación y de Servicios Químicos y Microbiológicos (CEQIATEC), Escuela de Química, \\ Tecnológico de Costa Rica, Cartago, Costa Rica \\ Email:vmontero@itcr.ac.cr
}

Received 21 April 2016; accepted 24 May 2016; published 27 May 2016

Copyright $\odot 2016$ by authors and Scientific Research Publishing Inc. This work is licensed under the Creative Commons Attribution International License (CC BY). http://creativecommons.org/licenses/by/4.0/

(c) (i) Open Access

\section{Abstract}

Natural contamination of world groundwater supplies with arsenic of volcanic origin has become a complicated and growing problem given current shortage of water. Maintenance cost of treatments that are based on ion exchange and reverse osmosis is considered high, in addition to the high production of sludge with such methods. On the other hand, efficiency of treatments employing coagulation/filtration is usually relative, depending on the method of application. Currently, emerging treatments that use nanotechnology are gaining relevance, due to their high efficiency and low cost. These methods are highly selective, with minimum generation of toxic wastes, as long as particle release into the environment is kept under control to avoid health risks. The present study developed filters with magnetic nanoparticles of $\mathrm{Fe}_{3} \mathrm{O}_{4}$ (magnetite) supported on porous silica $\left(\mathrm{Fe}_{3} \mathrm{O}_{4} @ \mathrm{SiO}_{2}\right)$ at a mass ratio of 2:1. The nanoparticles were synthetized by co-precipitation of $\mathrm{Fe}(\mathrm{II})$ and $\mathrm{Fe}(\mathrm{III})$ using $\mathrm{NH}_{4} \mathrm{OH}_{(\mathrm{ac})}$ under inert atmosphere. Average sizes of $15 \mathbf{~ n m}$ were obtained, measured by means of Transmission Electronic Microscopy (TEM) and characterized by X-ray Powder Diffraction (XRD); the magnetic power was qualitatively determined. The efficiency of the composite material $\left(\mathrm{Fe}_{3} \mathrm{O}_{4} @ \mathrm{SiO}_{2}\right)$ was determined in a prototype laboratory with a height of $60 \mathrm{~cm}$ and a diameter of $5 \mathrm{~cm}$, assembled with five filters of the composite material, with $1 \mathrm{~g}$ each filter. The filters were wrapped in resistant water-porous fabric to favor continuous flow at a ratio of $0.015 \mathrm{~L} / \mathrm{min}$. The test was performed with arsenic solutions at $(43.7 \pm 2.1 \mu \mathrm{g} / \mathrm{L})$, similar to the amount present in water supplies currently treated in Costa Rica. The removal was completed in 7 minutes with 0 N.T.U and less than $10 \mu \mathrm{g} / \mathrm{L}$ arsenic concentration (maximum limit allowed in Costa Rica), quantified by Atomic Absorption Spectrometry with Hydride Generation. After the reaction filters, the prototype was assembled with cleaning filters at a ratio of $1: 8$. The final way out was through a magnetized tube to ensure that no nanoparticles were released outside with the water, thus contributing to nanotoxicology safety for people and the environment. 


\section{Keywords}

\section{Magnetite, Drinking Water, Arsenic, Nanotoxicology}

\section{Introduction}

Arsenic is an element that has attracted people's attention since ancient times. It used to be considered as a powerful poison, and it is now in the news as a result of a largest environmental calamity in Asia. This has led to the rediscovery of arsenic despite it always exists in the environment as a "silent" toxic agent in the world. Every year, new areas with arsenic in environments exceeding the maximal contamination levels set by international organizations are identified. Arsenic is a natural or anthropogenic contaminant in areas where human subsistence is a risk. It comprises a large number of chemical species with a wide variation in toxicity [1].

At least, four million people in several countries in Latin America-Argentina, Chile, El Salvador, Nicaragua, Mexico, Peru and Bolivia among them-drink water having levels of arsenic that put their health at risk [2]; toxic effect of arsenic on humans varies, probably due to genetic, metabolic, diet factors, as well as health condition, sex and age. Population's susceptibility to exposure to one or more environmental toxic agents may be incremented by poverty conditions. Reduced access to opportune medical care caused by poverty also elevates vulnerability of the population [3].

Arsenic effects in population worldwide go from slight changes in pigmentation on face, neck and back, to cutaneous lesions and hyperkeratosis. Effects appear after five years minimum exposure and may evolve into skin cancer. Later on, or because of ingesting high concentrations of arsenic, other problems may occur, such as digestive, hepatic, renal, cardiovascular, neurological, haematological, reproductive and learning problems, and diabetes [2]. Arsenic is considered a powerful nephrotoxic, linked to kidney failure [2], which a major pathology in Costa Rica and Central America [4]-[6].

\subsection{Exposure and Toxicology of Arsenic}

Combined exposures to lead, cadmium and arsenic are common in both occupational and environmental situations [7] [8]. Since all three elements are nephrotoxic, additive or synergistic manifestations of renal cell injury are frequently reported depending on dose or exposure level. Toxic effects on renal tubule cells from combined lead and arsenic exposures have been reported following both moderate and low level dosing of experimental animals in vivo [9] [10].

The clinical manifestations of such arsenic exposures on the kidney are consistent across studies and may involve effects on the blood vasculature [11] [12] leading to axotemia and/or tubular toxicity, and in some studies renal carcinogenesis. The renal proximal tubules are a major metabolic component of the kidney, which is responsible for reabsorption of proteins, glucose, and electrolytes from the urinary filtrate [13]. Renal proximal convoluted tubule cells (PCTCs) have high energy requirements in the form of ATP in order to meet their metabolic functions for the kidney and for this reason contain many mitochondria [14] that are highly sensitive to arsenical inhibition of respiration [15]. The high metabolic activity of the renal PCTCs coupled with their high mitochondrial content combine to make these cells and this portion of the renal nephrons major targets for arsenical toxicity. According to data provided by Correa-Rotter et al., 2014, in Mesoamerican Nephropathy, tubules and kidney interstitium are the kidney structures predominantly affected [5].

\subsection{Treatment and Arsenic Removal}

In view of the toxic effects of As to human health, it becomes important to remove it from the environment. Some of the most common technologies for arsenic removal include oxidation, coagulation/precipitation, adsorption, ion exchange, electrocoagulation, and membranes [16] [17]. Among these removal methods, adsorption has proven to be the best method because of its versatility and affordability [18]. Additionally, adsorbent materials can be regenerated and reused and in this way the amount of generated waste material is considerably reduced [19]. The affordability of adsorbents makes them ideal to implement in third-world countries [20] and in small municipalities seeking to comply with standards. Some of the most widely used adsorbents for arsenic 
removal include activated alumina (AA), natural zeolites [21], and granular ferric oxide [22]. Among the most widely used nanoparticles, magnetic nanoparticles, mainly zero-valent iron (nZVI), magnetite $\left(\mathrm{Fe}_{3} \mathrm{O}_{4}\right)$ and maghemite $\left(\gamma-\mathrm{Fe}_{2} \mathrm{O}_{3}\right)$ nanoparticles, have sparked an immense interest in research for engineering applications for treatment of polluted water or subsurface environments [23] [24]. Adsorption process is also occurred on the iron oxides $\left(\mathrm{Fe}_{3} \mathrm{O}_{4} @ \mathrm{SiO}_{2}\right.$ and $\gamma$ - $\left.\mathrm{Fe}_{2} \mathrm{O}_{3}\right)$ surface, while $\mathrm{Fe}_{3} \mathrm{O}_{4}$ possess reducing power [25].

\subsection{Environmental Benefits of Nanotechnology and Use of Nanoparticles}

In recent years, there has been an increasing use of engineered magnetic nanoparticles for remediation and water treatments, leading to elevated public concerns. To this end, it is necessary to enhance the understanding of how these magnetic nanoparticles react with contaminants and interact with the surrounding environment during applications.

The large contaminants removal capacity and fast reaction rate of the magnetic nanoparticles are the major advantages. The total surface area of particles with the same mass increases tremendously (can add up to a thousand times), when the particle size decreases to nano-scale [26]. Due to the high surface-area-to-volume ratio, thus increase of active sites for the reaction, the mass required for treatment processes can be less than the case using the micro-sized counterparts. Various studies showed that the removal capacity and reactivity of nanoparticles are highly size dependent. [27]-[29] reported that the removal capacity of $\mathrm{Fe}_{3} \mathrm{O}_{4}$ nanoparticles (8 $\mathrm{nm})$ was about seven times higher than that of coarse-grained counterparts $(50 \mathrm{~mm})$.

\subsection{Desorption of Contaminants and Recovery of the Nanoparticles}

Using magnetic nanoparticles for contaminant removal has proven to be a highly efficient technology. Desorption is desirable for controlled applications; but this can lead to a disaster of pollutant migration and spreading out if desorption occurs when the spent magnetic nanoparticles are released into the environment in an uncontrolled manner [25].

One of the most important characteristics of magnetic nanoparticles, showing advantage over other nanoparticles, is their magnetism. Abundant evidence showed that magnetic properties of particles alter when particle size reaches nanoscale [30]. In particular, the magnetic property of $\mathrm{Fe}_{3} \mathrm{O}_{4}$ and $\gamma-\mathrm{Fe}_{2} \mathrm{O}_{3}$ changed from ferromagnetic to superparamagnetic [31]. This property offers an encouraging option, satisfying requirements of high accessibility as well as reusability. Most water or wastewater treatment systems require a settling, filtration or centrifuge process to separate solids like sludge. However, magnetic nanoparticles can be separated and recovered with an external magnetic field due to the intrinsic magnetic characteristic of the nanoparticles, aiding in prominent nanoparticles recovery without a filtration process.

When considering the applicability of magnetic nanoparticles for treatment technologies, another major consideration is the reusability of magnetic nanoparticles. To maintain reactivity, physical and chemical properties of the nanoparticle products, the synthesis and manufacturing process of nanoparticles require meticulous control of conditions. The treatment cost of applying nanoparticles is relatively high, compared with traditional treatments. For instance, the Price of $1 \mathrm{~kg}$ of $\gamma-\mathrm{Fe}_{2} \mathrm{O}_{3}$ nanoparticles is ranging from USD 180 to 380, depending on the particle size, purity and methods of synthesis [32]; Reuse of nanoparticles would substantially reduce the treatment cost. Regeneration is a common to regain the removal capacity of adsorbents, whilst feasibility of regeneration of magnetic nanoparticles is closely related to their removal mechanism.

\subsection{Risks Associated with the Use of Nanoparticles in the Environment}

The rapid expansion of nanotechnology promises to have great benefits for society, yet there is increasing concern that human and environmental exposure to engineered nanomaterials may result in significant adverse effects. That is why the field of nanotoxicology-dealing with effects and potential risks of particulate structures $<100$ $\mathrm{nm}$ in size-has emerged, growing significantly over the past decade from long-standing foundations of well established knowledge on the toxicology of fibrous and non-fibrous particles and the interactions of viruses with cells.

Discoveries of nanoparticle-specific concepts of toxicology related to their small size and large specific surface area go back to the early parts of the past century, although the distinctive biological effects and kinetics of nanoparticles were not recognized until the last decade of the past century [33]. 
Studies also illustrated that nanoparticles have the ability to enter organisms during ingestion or inhalation [34] and can translocate within the body to various organs and tissues [35] where the nanoparticles have the possibility to exert the reactivity being toxicology effects. Although some studies have also addressed the toxicological effects of nanoparticles on animal cells [36] [37].

Adsorption of magnetic nanoparticles on the bacteria membrane surface, and the reactions internally in cytoplasm of bacteria were reported to be the causes of bactericidal effect [38]-[40]. However, the mechanism of toxicity is still unclear and biocompatibility varies depending on numerous parameters, such as nanoparticle size and shape, surface property, applied nanoparticle concentration, type of cell and nanomaterial.

The specific gene alteration and hierarchical clustering revealed that SPIONs-COOH altered genes associated with cell proliferative responses due to their reactive oxygen species (ROS) properties. It was also found that the cell type can have quite a significant role in the definition of suitable pathways for detoxification of NPs, which has deep implications for the safe and high yield design of NPs for biomedical applications and will require serious consideration in the future [41].

\subsection{Nanotoxicology, an Emerging Concept}

The small size facilitates uptake into cells and transcytosis across epithelial and endothelial cells into the blood and lymph circulation to reach potentially sensitive target sites such as bone marrow, lymph nodes, spleen, and heart. Access to the central nervous system and ganglia via translocation along axons and dendrites of neurons has also been observed. The greater surface area per mass compared with larger-sized particles of the same chemistry renders nanoparticles more active biologically. This activity includes a potential for inflammatory and pro-oxidant, but also antioxidant, activity, which can explain early findings showing mixed results in terms of toxicity of nanoparticles, to environmentally relevant species [42].

The research findings on the toxic effects of magnetic nanoparticles have generally focused on "clean" particles. However, during environmental applications of magnetic nanoparticles, various contaminants could interact with the particles and alter their physiochemical properties. Magnetic nanoparticles may act as contaminant carriers, if the "used" magnetic nanoparticles are internalized by cells. A synergistic toxic effect could be a consequence in this ternary system, cells-contaminants-magnetic nanoparticles, where the bioavailability of loaded magnetic nanoparticles and its affinity towards bacterial cells have yet to be studied. One should also note that the type of bacteria plays a critical role on bactericidal effects, since different bacteria have a different tolerance on oxidative stress and exposure to nanoparticles [43].

For instance, autotrophic bacteria can utilize chemical energy which can probably withstand the high reactivity of nanoparticles [44] [45]. The strain of bacteria, gram positive or negative, also exhibits varying resistances to magnetic nanoparticles where electrostatic interactions may be taken into account [46] [47]. Other microbes like fungi have a more robust structure and are less sensitive to the environmental disturbance than bacteria [46], these are also abundant in natural environments. In addition, the bactericidal ability of magnetic nanoparticles can be utilized in a beneficial way as a disinfecting and sedimentation agent [46] [48].

\subsection{Phytotoxicity of Magnetic Nanoparticles}

The research data on the environmental effects and bioavailability of magnetic nanoparticles is still limited, especially on phytotoxicity, although the toxicological effects of several other types of nanoparticles, such as fullerenes, carbon nanotubes, titanium dioxide and silver, have been widely studied [49]-[52]. Since plants are essential constituents in ecosystems, and probably a pathway for magnetic nanoparticles transport and bioaccumulation along food chain, the recent findings on phytotoxicity of magnetic nanoparticles are discussed.

Various experimental methods including in vitro study with isolated plant cells, a whole plant, or seeds as well as various experimental setups such as water, soft agar medium, and nature soil have been applied [50]. The evidence on the phytotoxicity of nanoparticles is yet conclusive because it likely depends on the plant species, composition, concentration, size and surface properties of the nanoparticles, and experimental methods.

Although diverging results of the phytotoxicology of the magnetic nanoparticles were reported, a comparatively conclusive finding showed that the presence of soil or sand reduced the impacts of magnetic nanoparticles on plants. The magnetic nanoparticles tend to attach or deposit on soil or sand grains, leading to a reduction of availability of magnetic nanoparticles [53] [54]. Several recent research papers reported the uptake of magnetic nanoparticles from aqueous medium by different plant species, such as pumpkin [54]. 
The magnetic nanoparticles can also lead to little growth of leaves and death of older leaves (grown before dosing of nanoparticles). On the contrary, It was also reported that the magnetic nanoparticles could be taken up and translocated in plants, without any apparent visual impact, and could even enhanced the plant growth at low concentration [55].

Taken together with the toxicology effects on bacteria, surface modifiers can reduce degree of toxicity on both plants and bacteria, probably due to reduction of attachment, and thus bioavailability. Moreover, the attachment of magnetic nanoparticles to soil medium resulted in lower the toxic impacts, suggesting that magnetic nanoparticles at low concentration could be used for environmental engineering applications without pernicious effects on plants [55].

The aim of the research was to develop a nature-friendly selective treatment, applying updated technology and at a reasonable cost, intended to be employed in the way out of medium flow wells.

\section{Methods}

\subsection{Synthesis of $\mathrm{Fe}_{3} \mathrm{O}_{4} @ \mathrm{SiO}_{2}$}

A $\mathrm{Fe}_{3} \mathrm{O}_{4} @ \mathrm{SiO}_{2}$ composite was used as remover of arsenic species. This composite material was prepared using co-precipitation of $\mathrm{Fe}(\mathrm{II})$ and $\mathrm{Fe}(\mathrm{III})$ with $\mathrm{NH}_{4} \mathrm{OH}(\mathrm{ac})$ onto $\mathrm{SiO}_{2}$, using a method similar to the one proposed by Petcharoen and Sirivat [56] with some modifications. All processes were carried out under $\mathrm{N}_{2}(\mathrm{~g})$ atmosphere at room temperature. In a typical procedure, $\mathrm{SiO}_{2}$ was dispersed in a solution containing $\mathrm{Fe}(\mathrm{II})$ and $\mathrm{Fe}(\mathrm{III})$ cations under inert atmosphere. After that, $\mathrm{Fe}_{3} \mathrm{O}_{4}$ nanoparticles were deposited over the $\mathrm{SiO}_{2}$ substrate using concentrated $\mathrm{NH}_{4} \mathrm{OH}(\mathrm{ac})$ (equivalent to $28.0 \% \mathrm{w} / \mathrm{w} \mathrm{NH} \mathrm{NH}_{3}$ in water) as precipitating agent. The resulting material was washed with water until neutral pH. The $\mathrm{Fe}_{3} \mathrm{O}_{4} @ \mathrm{SiO}_{2}$ composite obtained had a support-magnetite mass ratio of 2:1. A similar procedure developed without the $\mathrm{SiO}_{2}$ was done to obtain single $\mathrm{Fe}_{3} \mathrm{O}_{4}$ nanoparticles. In the latter case, the single $\mathrm{Fe}_{3} \mathrm{O}_{4}$ nanoparticles were stabilized with carboxylic acid, dispersing the $\mathrm{Fe}_{3} \mathrm{O}_{4}$ nanoparticles in a solution of the carboxylic acid in methanol and then removing the excess of the acid by washing with methanol.

\subsection{Characterization of Single $\mathrm{Fe}_{3} \mathrm{O}_{4}$ Nanoparticles and $\mathrm{Fe}_{3} \mathrm{O}_{4} @ \mathrm{SiO}_{2}$}

XRD data of single $\mathrm{Fe}_{3} \mathrm{O}_{4}$ nanoparticles and $\mathrm{Fe}_{3} \mathrm{O}_{4} @ \mathrm{SiO}_{2}$ were acquired with a PANalytical Empyrean diffractometer with Cok $\alpha 1$ radiation. Each pattern was obtained in the $2 \theta$ range of $15.0091^{\circ}-84.9881^{\circ}$ with steps of $0.0130^{\circ}$. The scan step times were $13.7700 \mathrm{~s}$ for the single $\mathrm{Fe}_{3} \mathrm{O}_{4}$ nanoparticles sample and $37.9950 \mathrm{~s}$ for the $\mathrm{Fe}_{3} \mathrm{O}_{4} @ \mathrm{SiO}_{2}$ composite. TEM micrographs were obtained for the single $\mathrm{Fe}_{3} \mathrm{O}_{4}$ nanoparticles using a JEOL JEM-2100 microscope with an accelerating voltage of $100 \mathrm{kV}$.

\subsection{Laboratory Scale Filtration System}

A scalable lab system using filtering down through porous materials $\mathrm{Fe}_{3} \mathrm{O}_{4} @ \mathrm{SiO}_{2}$ was implemented in order to study the performance of the removers using continuous flow. Filters with $\mathrm{Fe}_{3} \mathrm{O}_{4} @ \mathrm{SiO}_{2}$ composite material were produced, wrapped in semipermeable fabric allowing water flow, containing $1 \mathrm{~g}$ of composite material each filter. Several tests were needed to determine the appropriate number of filters per tested arsenic solution volume.

Then, activated carbon bed filters were assembled to the system, in order to reduce turbidity of filtered water coming through the composite material filters. The activated carbon bed filters were placed in the system at a ratio of $8: 1$ with respect to the composite material filters. Following, the water flows through a $0.45 \mu \mathrm{m}$ filter, to finally come out through a magnetized tube that can remove all magnetic nanoparticles that may have been liberated.

A solution prepared in the laboratory with arsenic reagent grade with a concentration of $(43.7 \pm 2.1 \mu \mathrm{g} / \mathrm{L})$ was used to carry out performance measurements of the filters mentioned above. Following this trial, the performance of the filtration system was tested using the water entering the treatment system at Bebedero, Cañas, Guanacaste in Costa Rica.

Total As in water samples was analyzed using Perkin Elmer AAnalyst-800 atomic absorption spectrometer with a FIAS-100 hydride generation system. All measurements were carried out using a method with a detection limit of $0.71 \mu \mathrm{g} / \mathrm{L}$ and a quantification limit of $2.38 \mu \mathrm{g} / \mathrm{L}$. Alternatively, simple field test measurements were done using a test kit Lovibond ${ }^{\circledR}$, previously validated using the Atomic Absorption Spectroscopy analysis method. 


\section{Results}

\subsection{Measurement and Characterization of the Synthetized Nanoparticles}

Obtaining the smallest particle size possible is essential for a successful synthesis of nanoparticles. Once prepared for visualization through the electronic transmission microscope, the samples were analyzed to determine average size. The $\mathrm{Fe}_{3} \mathrm{O}_{4}$ magnetite nanoparticles obtained showed irregular shape with an average size of $15 \mathrm{~nm}$, calculated by means of TEM. Figure 1 shows a TEM micrograph of bare particles.

Figure 2 shows the XRD measurements developed for the samples $\mathrm{Fe}_{3} \mathrm{O}_{4} @ \mathrm{SiO}_{2}$ [2(a)] and single $\mathrm{Fe}_{3} \mathrm{O}_{4}$ [2(b)]. The XRD pattern for $\mathrm{Fe}_{3} \mathrm{O}_{4} @ \mathrm{SiO}_{2}$ presents a broad signal between $17^{\circ}$ and $34^{\circ}$ indicating the presence of amorphous silica as well as another group of signals that clearly matches with the ones presented for single bare $\mathrm{Fe}_{3} \mathrm{O}_{4}$ nanoparticles, this evidence the actual incorporation of $\mathrm{Fe}_{3} \mathrm{O}_{4}$ onto the porous support. The presence of the magnetite gives to the materials important magnetic characteristics. This could be determined qualitatively in the samples using a magnet, one that led in all cases a migration of the particles in contact with the magnet through a glass.

\subsection{Quantification of the Efficiency of the Composite Material by Means of a Laboratory Prototype}

In order to quantify the efficiency of the nanoparticles on the support material and to scale up the results to a field device, the determination of the efficiency of the composite material $\left(\mathrm{Fe}_{3} \mathrm{O}_{4} @ \mathrm{SiO}_{2}\right)$ was carried out in a prototype laboratory consisting of a continuous flow system. Filter testing was performed starting with 25 filters per time, down to a minimum of 5 filters, concluding that this last number of filters of the composite material may have acted efficiently in the prototype. Work was carried out with continuous flow at a ratio of $0.015 \mathrm{~L} / \mathrm{min}$, tested with a laboratory solution of arsenic at $43.7 \pm 2.1 \mathrm{mg} / \mathrm{L}$. The resulting concentrations of arsenic in each

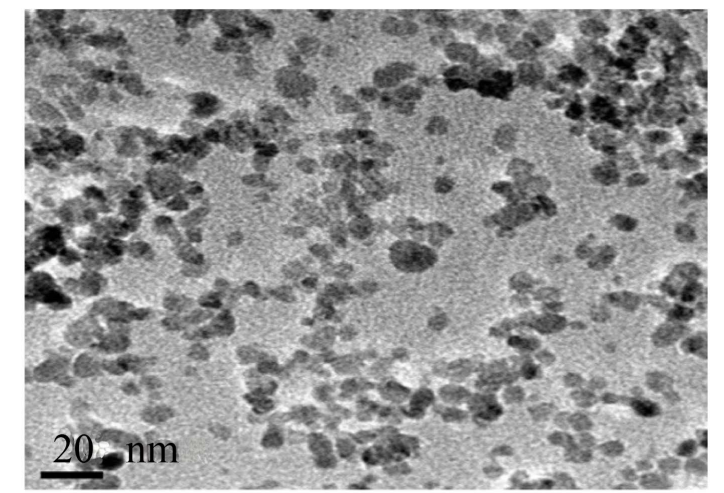

Figure 1. TEM image of the bare magnetite nanoparticles with average size of $15 \mathrm{~nm}$.

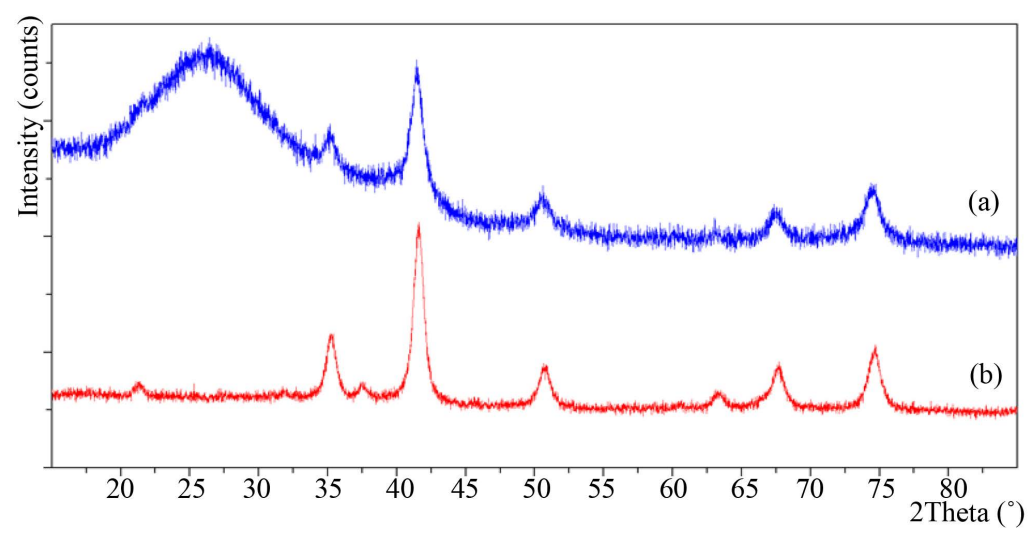

Figure 2. XRD patterns of $\mathrm{Fe}_{3} \mathrm{O}_{4} @ \mathrm{SiO}_{2}$ (a) and single $\mathrm{Fe}_{3} \mathrm{O}_{4}$ nanoparticles (b). 
volume of sample filtered through the composite material were found to be lower than the detection limit of the atomic absorption equipment (pointed green line).The graphics presented on Figure 3 was generated.

It was found that the filters could treat an important amount of water with arsenic. In view of their high performance, it was decided to estimate the projected quantity of water that could be treated with the same filters. The yield volume of the composite material of the prototype was calculated, continuing the trend line. A straight line equation was used for calculation. Figure 4 shows the trend from $9 \mathrm{~L}$ of arsenic solution prepared in the laboratory and passed through the filters. The productivity of the filters was estimated in $50 \mathrm{~L}$.

Once filter efficiency was determined under laboratory conditions, the filtration system was tested using raw untreated water from the Northern zone of the country, contaminated with arsenic at a concentration of 13.3 $\mu \mathrm{g} / \mathrm{L}$. This area, called Bebedero de Cañas, is characterized by having high $\mathrm{pH}$ of 8.1 and total hardness of 83 $\mathrm{mg} / \mathrm{L}$, which is considered as medium hardness. It is important to determine the performance of the nano-particles under such conditions, since a previous treatment may be necessary in order to pass water through the filters and these accomplishing the task of selective arsenic absorption. Performance of the filters is shown in Figure 5.

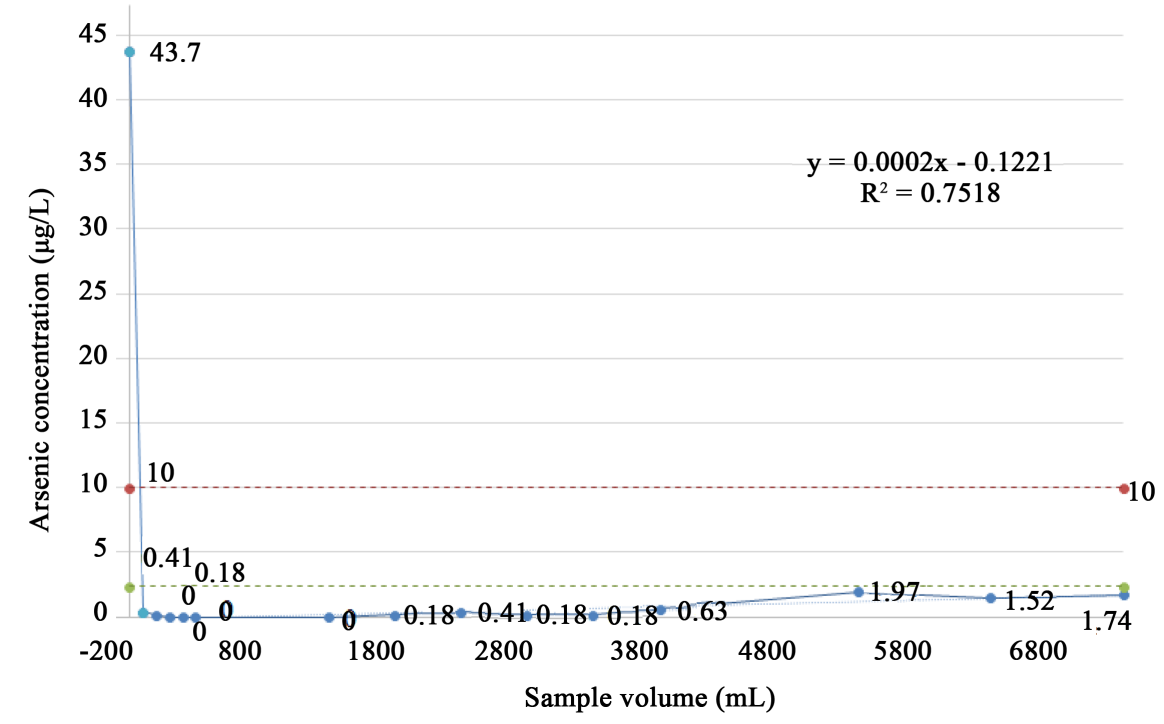

Figure 3. Stability test of the composite material $\mathrm{Fe}_{3} \mathrm{O}_{4} @ \mathrm{SiO}_{2}$. The red line indicates the maximum allowed by legislation in Costa Rica, which is $10 \mu \mathrm{g} / \mathrm{L}$.

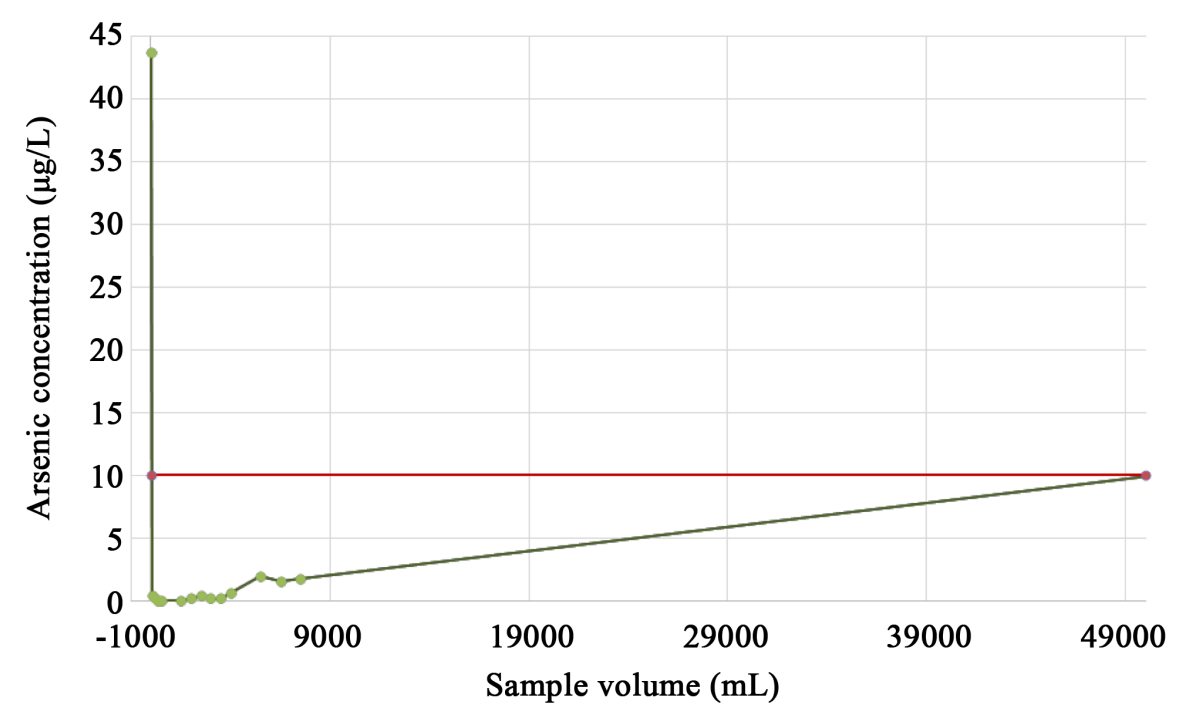

Figure 4. Stability test of the composite material $\mathrm{Fe}_{3} \mathrm{O}_{4} @ \mathrm{SiO}_{2}$. 


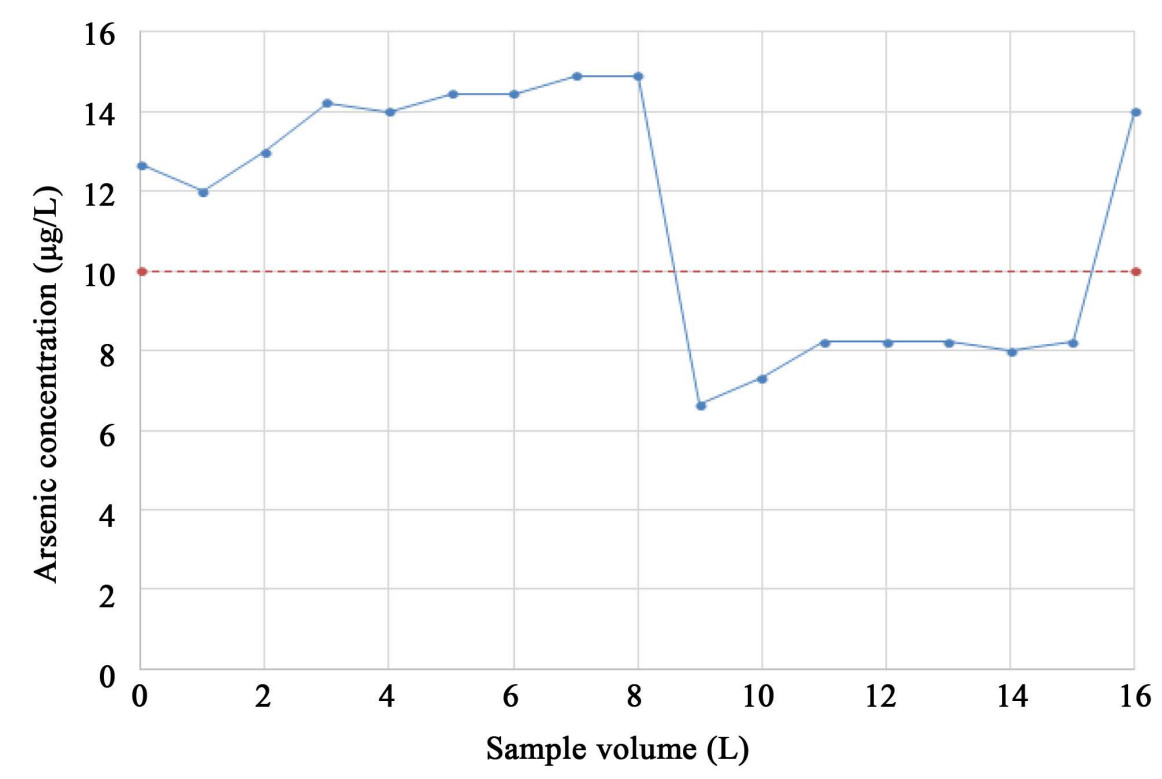

Figure 5. Arsenic removal at arsenic treatment system in Bebedero, Cañas. After $8 \mathrm{~L}$ the cleaning filters are changed, thus showing their incidence on the system performance is important.

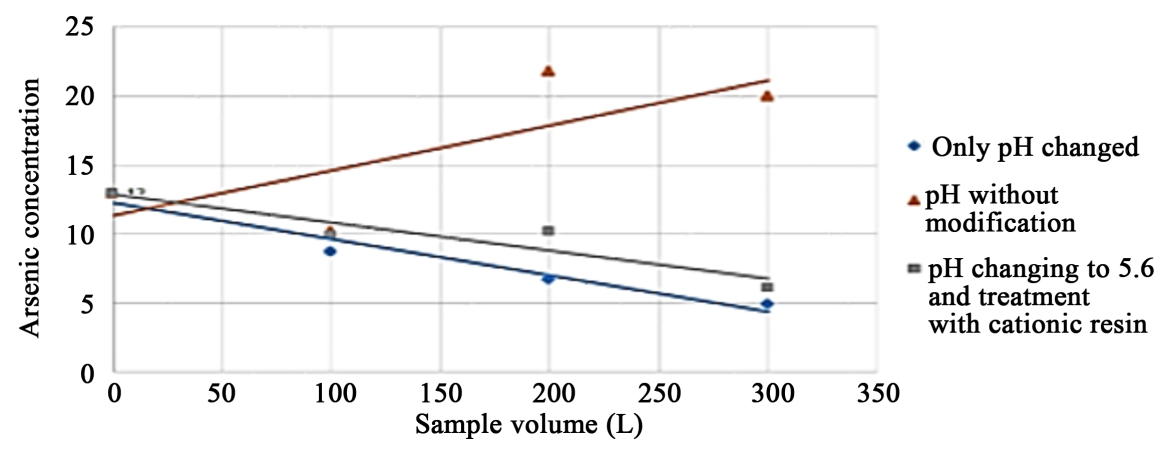

Figure 6. Comparison of water treatments at the arsenic treatment system in Bebedero, with and without modification of the $\mathrm{pH}$ and cationic exchange treatment.

As can be observed, while the water presents high $\mathrm{pH}$ and high hardness, there is interaction with the nanoparticle charges of the composite material, which causes that after being adsorbed, the arsenic is released, which can be observed in the ascending behaviour of the graphics. In addition, cleaning filters play an important role in arsenic retention by the system; however, the filters become rapidly saturated with interaction of the charges, as shown in Figure 5.

For the above reasons, three tests were performed: test 1-water $\mathrm{pH}$ in Bebedero was changed from 8.1 to 5.6; test 2-pH was modified and the sample was put through a resin for cationic exchange; and test 3-the sample received the resin treatment to reduce hardness only. All this was performed to determine the influence of high water $\mathrm{pH}$, high water hardness or both, on the efficiency and arsenic removal capability of the filtration system. Figure 6 shows the behaviour of the treatments.

As shown in Figure 6, only by lowering the initial $\mathrm{pH}$ of the water entering the system to 5.6, the required arsenic removal efficiency is attained.

\section{Discussion}

Synthesis and characterization of magnetic nanoparticles of $\mathrm{Fe}_{3} \mathrm{O}_{4}$ were obtained. The advantages of these materials are known: efficiency and high performance, high specificity, low cost since they were synthesized in our 
laboratory from common reagents and minimal waste release into the environment after their reaction in the water. Because of their intrinsic magnetism, the nanoparticles can be separated and recovered with an external magnetic field, which in this case is a magnetized exit tube in the filtration system.

Due to the close relationship surface-area-volume, active reaction sites increase, and the amount required for the treatment processes can be much less than in other similar treatments, since removal capacity and reactivity of nanoparticles are highly size dependent. In this case, the nanoparticles obtained had an average size of $15 \mathrm{~nm}$, therefore it was possible to find particles of $10 \mathrm{~nm}$ or less in the material, which is the reason for the high efficiency found.

\subsection{Characterization of the Synthetized Nanoparticles}

High performance material was obtained, with average nanoparticle sizes of $15 \mathrm{~nm}$; proven high efficiency; low cost and easily reproducible, because of the type of materials used. Appropriate material characterization was achieved; its magnetic nature was identified and nanoparticles were collected in the magnetized tube at the end, thus avoiding nanoparticle release into the environment in order to respect basic concepts of nanotoxicology.

By depositing nanoparticles on a support of porous silica $\left(\mathrm{Fe}_{3} \mathrm{O}_{4} @ \mathrm{SiO}_{2}\right)$, an important stability of this composite material is obtained, thus increasing the yield of the reaction of adsorption of arsenic in the treated water.

Added to the above advantages is the possibility of recovery of the material, which allows substantial reduction of the overall cost of treatment. Regeneration of the composite material and capacity of adsorbent removal is made possible when using absorption-based treatments.

\subsection{Efficiency of the Composite Material}

Performance of the composite material using arsenic solutions, in both laboratory solutions and in water for use in populations currently affected was validated by means of the filtration system assembled as a prototype laboratory. Although the maximum amount of admissible arsenic in water is surpassed by only $3 \mu \mathrm{g} / \mathrm{L}$ in the population under study, the cost of treatment is very high.

With the proposed system, the number of filters used can be increased, depending on the amount of arsenic to be treated in each particular case, and the volume of water in each system, and its parts may be changed independently, depending on the specific wear.

It was found that the impact of the $\mathrm{pH}$ is very high on the performance and water treatment under this system. According to the specific nature of each type of water to be treated it is essential-as is the case of the Bebedero System in Cañas-to lower the $\mathrm{pH}$ from 8.1 to 5.6. The results showed that when passing through the cleaning filters, the $\mathrm{pH}$ increases again.

The addition to the filtration system of an end tube to collect magnetized nanoparticles makes this kind of treatment an environmentally friendly option because it prevents the intrinsic nanotoxicity of these particles. Because of their small size, nanoparticles can enter directly into the cell, causing undetermined damage.

\section{Conclusions}

While in Costa Rica water sources are not highly contaminated with arsenic, as is the case of many countries worldwide, the National Water Institute has been concerned about giving effective treatment to water sources for massive consumption, where the amount of arsenic exceeds the maximum allowed $(10 \mu \mathrm{g} / \mathrm{L})$, although the treatments currently used in this country are costly.

The filtration system using downward continuous flow through magnetic composite material $\left(\mathrm{Fe}_{3} \mathrm{O}_{4} @ \mathrm{SiO}_{2}\right)$ is currently in the process of registration at the University, awaiting for funds for the construction of field systems.

The present work offers a highly efficient technological and low cost system that can be placed at the water outlet of wells prior to water disinfection. This method also prevents release of nanoparticles, taking into account basic principles of nanotoxicology and respect for the environment. Once treated and chlorinated afterwards, the water may be safely consumed by the population.

\section{Acknowledgements}

We would like to thank Vicerrectoría de Investigación y Extensión from Tecnológico de Costa Rica for their financial support. The researchers Dr Ricardo Starbird Pérez and MSc.Jorge Calvo Gutierrez from Escuela de 
Química and Ing. Luis Fernando Alvarado from Microscopy Laboratory, for their contributions to research. We are also grateful to the students Ana Victoria Cubero, José Pablo Cerdas, Ana Lucía Moya, Kalet Hernández and Marit Möller for their assistance.

\section{Conflict of Interest Statement}

The authors declare that there is no conflict of interest.

\section{References}

[1] Litter, M., Nicolli, H., Meichtry, M., Bundschuh, J,, Bhattacharya, P. and Naidu, R. (2014) One Century of the Discovery of Arsenicosis in Latin America (1914-2014). Arsenic and the Environment Proceedings, Argentina, CRC Press.

[2] Swaran, J. and Singh, F. (2014) Handbook of Arsenic Toxicology. Elsevier, 365-380.

[3] Navoni, J.A., De Pietri, D., Garcia, S. and Villamil, L. (2012) Riesgo sanitario de la población vulnerable expuesta al arsénico en la provincia de Buenos Aires, Argentina. Revista Panamericana de Salud Pública, 31, 1-8. http://dx.doi.org/10.1590/S1020-49892012000100001

[4] Cuadra, S.N., Jakobssson, K., Hogstedt, C., et al. (2009) Chronic Kidney Disease in Central America: Assessment of Current Knowledge and Feasibility for Regional Research Collaboration in Central America. SALTRA Technical Series on Work \& Health 2, Heredia, Costa Rica, 73-89.

[5] Correa-Rotter, R., Wesseling, C. and Johnson, R.J. (2014) CKD of Unknown Origin in Central America: The Case for a Mesoamerican Nephropathy. American Journal of Kidney Diseases, 63, 506.

http://dx.doi.org/10.1053/j.ajkd.2013.10.062

[6] Laux, T.S., Barnoya, J., Guerrero, D.R. and Rothstein, M. (2015) Dialysis Enrollment Patterns in Guatemala: Evidence of the Chronic Kidney Disease of Non-Traditional Causes Epidemic in Mesoamerica. BMC Nephrology, 16, 54. http://dx.doi.org/10.1186/s12882-015-0049-x

[7] Bacigalupo, C. and Hale, B. (2012) Human Health Risks of Pb and As Exposure via Consumption of Home Garden Vegetables and Incidental Soil and Dust Ingestion: A Probabilistic Screening Tool. Science of the Total Environment, 423, 27-38. http://dx.doi.org/10.1016/j.scitotenv.2012.01.057

[8] Coelho, P., Costa, S., Silva, S., et al. (2012) Metal (Loid) Levels in Biological Matrices from Human Populations Exposed to Mining Contamination-Panasqueira Mine (Portugal). Journal of Toxicology and Environmental Health, Part A, 75, 893-908. http://dx.doi.org/10.1080/15287394.2012.690705

[9] Mahaffey, K.R., Capar, S.G., Gladen, B.C. and Fowler, B.A. (1981) Concurrent Exposure to Lead Cadmium and Arsenic: Effects on Toxicity and Tissue Metal Concentrations in the Rat. Journal of Laboratory and Clinical Medicine, 98, 463-481.

[10] Whittaker, M., Wang, G., Chen, X.-Q., et al. (2011) Effects of Trace Element Mixtures and the Production of Oxidative Stress Precursors: 30-Day, 90-Day, and 180-Day Drinking Water Studies in Rats. Toxicology and Applied Pharmacology, 254, 154-166. http://dx.doi.org/10.1016/j.taap.2010.10.025

[11] Chen, C.-J. (2011) Arseniasis in the World: From Endemic to Pandemic. In: Chen, C.-J. and Chiou, H.-Y., Eds., Health Hazards of Environmental Arsenic Poisoning: From Epidemic to Pandemic. World Scientific Publishing, Singapore, 1-20. http://dx.doi.org/10.1142/9789814291828_0001

[12] States, J.C., Srivastava, S., Chen, Y. and Barchowsky, A. (2009) Arsenic and Cardiovascular Disease. Toxicological Sciences, 107, 312-323. http://dx.doi.org/10.1093/toxsci/kfn236

[13] Sirac, C., Bridoux, F., Essig, M., Devuyst, O., Touchard, G. and Cogné, M. (2011) Towards Understanding Renal Fanconi Syndrome: Step by Step Advances through Experimental Models. Contributions to Nephrology, 169, $247-261$. http://dx.doi.org/10.1159/000313962

[14] Brown, M.M., Rhyne, B.C., Goyer, R.A. and Fowler, B.A. (1976) The Intracellular Effects of Chronic Arsenic Administration on Renal Proximal Tubule Cells. Journal of Toxicology and Environmental Health, 1, 507-516. http://dx.doi.org/10.1080/15287397609529349

[15] Zamora, P.I., Rockenbauer, A. and Villamena, F.A. (2014) Radical Model of Arsenic (III) Toxicity: Theoretical and EPR Spin Trapping Studies. Chemical Research in Toxicology, 27, 765-774. http://dx.doi.org/10.1021/tx4004227

[16] Litter, M.I., Morgada, M.E. and Bundschuh, J. (2010) Possible Treatments for Arsenic Removal in Latin American Waters for Human Consumption. Environmental Pollution, 158, 1105-1118. http://dx.doi.org/10.1016/j.envpol.2010.01.028

[17] Kobya, M., Gebologlu, U., Ulu, F., Oncel, S. and Demirbas, E. (2011) Removal of Arsenic from Drinking Water by 
Electrocoagulation Using Fe and Al Electrodes. Electrochimica Acta, 56, 5060-5070. http://dx.doi.org/10.1016/j.electacta.2011.03.086

[18] Lin, T.-F. and Wu, J.-K. (2001) Adsorption of Arsenite and Arsenate within Activated Alumina Grains: Equilibrium and Kinetics. Water Research, 35, 2049-2057. http://dx.doi.org/10.1016/S0043-1354(00)00467-X

[19] Mohan, D. and Pittman Jr., C.U. (2007) Arsenic Removal from Water/Wastewater Using Adsorbents-A Critical Review. Journal of Hazardous Materials, 142, 1-53. http://dx.doi.org/10.1016/j.jhazmat.2007.01.006

[20] Manna, B. and Ghosh, U.C. (2007) Adsorption of Arsenic from Aqueous Solution on Synthetic Hydrous Stannic Oxide. Journal of Hazardous Materials, 144, 522-531. http://dx.doi.org/10.1016/j.jhazmat.2006.10.066

[21] Camacho, L.M., Parra, R.R. and Deng, S. (2011) Arsenic Removal from Groundwater by $\mathrm{MnO}_{2}$-Modified Natural Clinoptilolite Zeolite: Effect of pH and Initial Feed Concentration. Journal of Hazardous Materials, 189, 286-293. http://dx.doi.org/10.1016/j.jhazmat.2011.02.035

[22] Giles, D.E., Mohapatra, M., Issa, T.B., Anand, S. and Singh, P. (2011) Iron and Aluminium Based Adsorption Strategies for Removing Arsenic from Water. Journal of Environmental Management, 92, 3011-3022. http://dx.doi.org/10.1016/j.jenvman.2011.07.018

[23] Hu, J., Lo, I.M.C. and Chen, G. (2004) Removal of Cr(VI) by Magnetite Nanoparticle. Water Science and Technology, 50, 139-146.

[24] Shen, Y.F., Tang, J., Nie, Z.H., Wang, Y.D., Ren, Y. and Zuo, L. (2009) Tailoring Size and Structural Distortion of $\mathrm{Fe}_{3} \mathrm{O}_{4}$ Nanoparticles for the Purification of Contaminated Water. Bioresource Technology, 100, 4139-4146. http://dx.doi.org/10.1016/j.biortech.2009.04.004

[25] Tang, S.C.N. and Lo, I.M.C. (2013) Magnetic Nanoparticles: Essential Factors for Sustainable Environmental Applications. Water Research, 47, 2613-2632. http://dx.doi.org/10.1016/j.watres.2013.02.039

[26] Tratnyek, P.G. and Johnson, R.L. (2006) Nanotechnologies for Environmental Cleanup. Nano Today, 1, 44-48. http://dx.doi.org/10.1016/S1748-0132(06)70048-2

[27] Nurmi, J.T., Tratnyek, P.G., Sarathy, V., Baer, D.R., Amonette, J.E., Pecher, K., Wang, C., Linehan, J.C., Matson, D.W., Penn, R.L. and Driessen, M.D. (2005) Characterization and Properties of Metallic Iron Nanoparticles: Spectroscopy, Electrochemistry, and Kinetics. Environmental Science and Technology, 39, 1221-1230. http://dx.doi.org/10.1021/es049190u

[28] Yean, S., Cong, L., Yavuz, C.T., Mayo, J.T., Yu, W.W., Kan, A.T., Colvin, V.L. and Tomson, M.B. (2005) Effect of Magnetite Particle Size on Adsorption and Desorption of Arsenite and Arsenate. Journal of Materials Research, 20, 3255-3264. http://dx.doi.org/10.1557/jmr.2005.0403

[29] Sneh, L. and Samadder, S.R. (2016) Review. Removal of Arsenic from Water Using Nano Adsorbents and Challenges: A Review. Journal of Environmental Management, 166, 387-406. http://dx.doi.org/10.1016/j.jenvman.2015.10.039

[30] Sundaresan, A. and Rao, C.N.R. (2009) Ferromagnetism as a Universal Feature of Inorganic Nanoparticles. Nano Today, 4, 96-106. http://dx.doi.org/10.1016/j.nantod.2008.10.002

[31] Chatterjee, J., Haik, Y. and Chen, C. (2003) Size Dependent Magnetic Properties of Iron Oxide Nanoparticles. Journal of Magnetism and Magnetic Materials, 257, 113-118. http://dx.doi.org/10.1016/S0304-8853(02)01066-1

[32] MKnano (2009) Nanoparticles. http://www.mknano.com

[33] Oberdörster, G., Stone, V. and Donaldson, K. (2007) Toxicology of Nanoparticles: A Historical Perspective. Nanotoxicology, 1, 2-25. http://dx.doi.org/10.1080/17435390701314761

[34] Holsapple, M.P., Farland, W.H., Landry, T.D., Monteiro-Riviere, N.A., Carter, J.M., Walker, N.J. and Thomas, K.V. (2005) Research Strategies for Safety Evaluation of Nanomaterials, Part II: Toxicological and Safety Evaluation of Nanomaterials, Current Challenges and Data Needs. Toxicological Sciences, 88, 12-17. http://dx.doi.org/10.1093/toxsci/kfi293

[35] Borm, P., Klaessig, F.C., Landry, T.D., Moudgil, B., Pauluhn, J., Thomas, K., Trottier, R. and Wood, S. (2006) Research Strategies for Safety Evaluation of Nanomaterials, Part V: Role of Dissolution in Biological Fate and Effects of Nanoscale Particles. Toxicological Sciences, 90, 23-32. http://dx.doi.org/10.1093/toxsci/kfj084

[36] Iversen, T.G., Skotland, T. and Sandvig, K. (2011) Endocytosis and Intracellular Transport of Nanoparticles: Present Knowledge and Need for Future Studies. Nano Today, 6, 176-185. http://dx.doi.org/10.1016/j.nantod.2011.02.003

[37] Moore, M.N. (2006) Do Nanoparticles Present Ecotoxicological Risks for the Health of the Aquatic Environment? Environment International, 32, 967-976. http://dx.doi.org/10.1016/j.envint.2006.06.014

[38] Auffan, M., Achouak, W., Rose, J., Roncato, M.-A., Chanéac, C., Waite, D.T., Masion, A., Woicik, J.C., Wiesner, M.R. and Bottero, J.-Y. (2008) Relation between the Redox State of Iron-Based Nanoparticles and Their Cytotoxicity toward Escherichia coli. Environmental Science and Technology, 42, 6730-6735. http://dx.doi.org/10.1021/es800086f

[39] Lee, C., Jee, Y.K., Won, I.L., Nelson, K.L., Yoon, J. and Sedlak, D.L. (2008) Bactericidal Effect of Zero-Valent Iron 
Nanoparticles on Escherichia coli. Environmental Science and Technology, 42, 4927-4933. http://dx.doi.org/10.1021/es800408u

[40] Tsuji, J.S., Maynard, A.D., Howard, P.C., James, J.T., Lam, C., Warheit, D.B. and Santamaria, A.B. (2006) Research Strategies for Safety Evaluation of Nanomaterials, Part IV: Risk Assessment of Nanoparticles. Toxicological Sciences, 89, 42-50. http://dx.doi.org/10.1093/toxsci/kfi339

[41] Mahmoudi, M., Laurent, S., Shokrgozar, M.A. and Hosseinkhani, M. (2011) Toxicity Evaluations of Superparamagnetic Iron Oxide Nanoparticles: Cell "Vision" versus Physicochemical Properties of Nanoparticles. ACS Nano, 5, 7263-7276. http://dx.doi.org/10.1021/nn2021088

[42] Oberdörster, G., Oberdörster, E. and Oberdörster, J. (2005) Nanotoxicology: An Emerging Discipline Evolving from Studies of Ultrafine Particles. Environmental Health Perspectives, 113, 823-839. http://dx.doi.org/10.1289/ehp.7339

[43] Manke, A., Wang, L. and Rojanasakul, Y. (2013) Review Article Mechanisms of Nanoparticle-Induced Oxidative Stress and Toxicity. BioMed Research International, 30, 1-10. http://dx.doi.org/10.1155/2013/942916

[44] Shin, K. and Cha, D.K. (2008) Microbial Reduction of Nitrate in the Presence of Nanoscale Zero-Valent Iron. Chemosphere, 72, 257-262. http://dx.doi.org/10.1016/j.chemosphere.2008.01.043

[45] Yu, X., Amrhein, C., Deshusses, M.A. and Matsumoto, M.R. (2006) Perchlorate Reduction by Autotrophic Bacteria in the Presence of Zero-Valent Iron. Environmental Science and Technology, 40, 1328-1334. http://dx.doi.org/10.1021/es051682z

[46] Diao, M. and Yao, M. (2009) Use of Zero-Valent Iron Nanoparticles in Inactivating Microbes. Water Research, 43, 5243-5251. http://dx.doi.org/10.1016/j.watres.2009.08.051

[47] Fajardo, C., Ortiz, L.T., Rodriguez-Membibre, M.L., Nande, M., Lobo, M.C. and Martin, M. (2012) Assessing the Impact of Zero-Valent Iron (ZVI) Nanotechnology on Soil Microbial Structure and Functionality: A Molecular Approach. Chemosphere, 86, 802-808.

[48] You, Y., Han, J., Chiu, P.C. and Jin, Y. (2005) Removal and Inactivation of Waterborne Viruses Using Zero-Valent Iron. Environmental Science and Technology, 39, 9263-9269. http://dx.doi.org/10.1021/es050829j

[49] Barrena, R., Casals, E., Colon, J., Font, X., Sanchez, A. and Puntes, V. (2009) Evaluation of the Ecotoxicity of Model Nanoparticles. Chemosphere, 75, 850-857. http://dx.doi.org/10.1016/j.chemosphere.2009.01.078

[50] Miralles, P., Church, T.L. and Harris, A.T. (2012) Toxicity, Uptake, and Translocation of Engineered Nanomaterials in Vascular Plants. Environmental Science and Technology, 46, 9224-9239. http://dx.doi.org/10.1021/es202995d

[51] Navarro, E., Baun, A., Behra, R., Hartmann, N.B., Filser, J., Miao, A.J., Quigg, A., Santschi, P.H. and Sigg, L. (2008) Environmental Behaviour and Ecotoxicity of Engineered Nanoparticles to Algae, Plants, and Fungi. Ecotoxicology, 17, 372-386. http://dx.doi.org/10.1007/s10646-008-0214-0

[52] Scown, T.M., Van Aerle, R. and Tyler, C.R. (2010) Review: Do Engineered Nanoparticles Pose a Significant Threat to the Aquatic Environment? Critical Reviews in Toxicology, 40, 653-670. http://dx.doi.org/10.3109/10408444.2010.494174

[53] El-Temsah, Y.S. and Joner, E.J. (2012) Impact of Fe and Ag Nanoparticles on Seed Germination and Differences in Bioavailability during Exposure in Aqueous Suspension and Soil. Environmental Toxicology, 27, 42-49. http://dx.doi.org/10.1002/tox.20610

[54] Zhu, H., Han, J., Xiao, J.Q. and Jin, Y. (2008) Uptake, Translocation, and Accumulation of Manufactured Iron Oxide Nanoparticles by Pumpkin Plants. Journal of Environmental Monitoring, 10, 713-717. http://dx.doi.org/10.1039/b805998e

[55] Ma, X., Gurung, A. and Deng, Y. (2013) Phytotoxicity and Uptake of Nanoscale Zero-Valent Iron (nZVI) by Two Plant Species. Science of the Total Environment, 443, 844-849. http://dx.doi.org/10.1016/j.scitotenv.2012.11.073

[56] Petcharoen, K. and Sirivat, A. (2012) Synthesis and Characterization of Magnetite Nanoparticles via the Chemical Co-Precipitation Method. Materials Science and Engineering B: Solid-State Materials for Advanced Technology, 177, 421-427. http://dx.doi.org/10.1016/j.mseb.2012.01.003 